\title{
FACTORS AFFECTING THE INTENTION TO PURCHASE TOWNHOUSE
}

\author{
Phuong Viet Le-Hoang \\ Ho Chi Minh City Open University, Vietnam \\ Industrial University of Ho Chi Minh City, Vietnam \\ E-mail: lehoangvietphuong@iuh.edu.vn \\ Vi Truc Ho \\ Industrial University of Ho Chi Minh City, Vietnam \\ E-mail:viht18707@sdh.uel.edu.vn \\ Nhan Trong Phan \\ Industrial University of Ho Chi Minh City, Vietnam \\ E-mail: nhanpt19707@sdh.uel.edu.vn \\ Truc Thanh Thi Le \\ Industrial University of Ho Chi Minh City, Vietnam \\ E-mail: lethithanhtruc@iuh.edu.vn \\ Submission: 7/15/2019 \\ Revision: 9/18/2019 \\ Accept: 10/2/2019
}

\section{ABSTRACT}

The purpose of this study is to identify the factors affecting the intention of buying a townhouse by customers in District 9, Ho Chi Minh City. To conduct the research, there is 192 valid respondents and the authors determine six factors affecting the intention of buying customers' houses in District 9 of Ho Chi Minh City: developer brand, price, location, housing characteristics, social influence and legal. The results of the exploratory factor analysis (EFA) show that all of these six factors affect the intention to buy townhouses in the District 9 area of customers. The contribution of the study is that the authors confirm the theory of Ajzen and Fishbein (1975), Ajzen (1985), Ajzen (1991) and compare some empirical studies of Salah et al. (2015), Julius et al. (2016), Haddad et al. (2011), Nguyen (2013), Vo (2013), Vo (2016), Pham (2013). Also, from qualitative and research-related studies, the authors adjusted the scale and analyzed data in the current context. 
DOI: 10.14807/ijmp.v11i6.1099

Based on that, research and propose solutions to improve the intention of buying houses in District 9 of customers and orienting for further research.

Keywords: Developer brand; price; location; housing characteristics; social influence; legal

\section{INTRODUCTION}

In the context of Vietnam's current economic development, buying a home to live in or invest has become more balanced than ever. In Ho Chi Minh City, With the advantage of being the gateway of the whole Southern region, District 9 is being invested by Ho Chi Minh City, synchronous planning on all items such as economy, culture, and society. Besides, District 9 also promises to bring "breakthrough" to the local real estate market in the coming time, thanks to the attraction of many investors' capital with the advantages: Fullbright University, Hightech zone with the world's leading corporations such as Samsung, Schneider, Intel, Microsoft.

However, customers still have concerns about buying houses for many reasons, such as many procedures, legal. It is unclear, and the price is too high. Because of not grasping customers' psychology, many real estate enterprises find it hard to find opportunities to reach customers. Therefore, the authors have conducted this research for customers to understand customer psychology, conditions better to meet current customers.

\section{LITERATURE REVIEW}

Buying intention is described as customer willingness to purchase products (TIRTIROGLU; ELBECK, 2008). Sales of the business can be surveyed based on the customer's purchase intent, and predicting the intention to buy is starting to predict the actual buying behavior of customers (HOWARD et al., 1967). Also, based on many theories, the intention to purchase is the basis for predicting future demand (WARSHAW, 1980; BAGOZZI, 1983; AIJEN; FISHBEIN, 1975).

Dodds et al. (1991) said that the intention to buy represents the ability of consumers to buy a specific product. Long et al. (2010) conclude that the intention to buy represents what an individual wants to buy in the future. The intention to buy is "what we think we will buy" (REZVANI et al., 2012). It can also be defined as an active decision that shows the behavior of the individual depends on the product (REZVANI et al., 2012).

Some previous studies point out the differences between the intention to buy and the actual purchase (WARSHAW, 1980; MULLET; KARSON, 1985; PICKERING; ISHERWOOD, 1974) and that difference is customer perception. However, it does not mean 
DOI: 10.14807/ijmp.v11i6.1099

that the study of intention is not meaningful. Some studies on the relationship of buying intentions and buying actions have made clear indications about this relationship (NEWBERRY et al., 2003; MOROWITZ; SCHMITTLEIN, 1992; BENNAOR, 1995; GRANBOIS; SUMMERS, 1974; SHEPPARD et al., 1988; MOROWITZ et al., 1996).

Theory of Reasoned Action (TRA) was developed by Ajzen and Fishbein (1975), Ajzen (1985) and according to TRA, the behavioral decision is the most critical factor to predict consumer behavior. Behavioral choices are influenced by two factors: attitude and social influence. In it: The attitude towards the decision is to express individual factors that reflect the positive or negative beliefs of consumers towards the product, and social influences show the influence of social relationships on individual consumers.

Due to the limitations of reasoned action theory model (TRA), Ajzen (1991) proposed a Theory of planned behavior (TPB) based on developing a rational action theory with the assumption that a behavior can be predicted or explained by decisions to be made that behavior. Decisions are assumed to include motivational factors that affect behavior and are defined as the level of effort that people try to perform. The act of planning affirms that behavioral decisions are a function of social attitudes and influences. Behavioral planning behavior awareness controls behavioral decisions.

Salah et al. (2015) collected data from 450 survey forms, and questionnaires were distributed to respondents in Jeddah. The model mentioned four factors that influence the intention to purchase Real estate that is attitude, master standard Interest, cognitive behavior, and finance. In which attitude is the most crucial factor affecting the selection of real estate purchase.

The model studied in the research topic "Understanding the factors affecting the intention to buy houses" is carried out by Harun et al. (2016) and Julius et al. (2016). The investigation team collected data from 235 working adults, and the findings show that the features of houses, finance, distance, environment, and superstitious numbers have a significant positive relationship with the intention to buy a house. The model shows the characteristics of the house, finance, distance, environment, and superstition have a positive relationship with the intention of buying a home.

Apaporn (2013) run the model that refers to factors affecting the decision to buy luxury apartments. This study is quantitative research, using random sampling methods from 400 data collection questions, the results show that the majority of respondents are single; their 
DOI: 10.14807/ijmp.v11i6.1099

education level is a bachelor's degree. Research results also show that price and location are a factor affecting customer decisions.

An empirical study by Haddad et al. (2011) concluded that the factors affecting the intention to buy apartments include: Economy, Beauty, Marketing, Social, Geography. This study found that there was a significant difference in the intentions regarding the purchase of gender-based apartments, age, and factors such as marital status and education, which were not significantly different. Also, the interest rate and income factors have a significant impact on the buying behavior of apartments in Jordan.

\section{HYPOTHESES DEVELOPMENT AND METHODOLOGY}

Prices may affect people's incentives to invest in real estate directly through housing needs and indirectly, through affecting inflation rates (DUA, 2007). Houses with identical physical properties may vary in market prices because prices include a set of specific utilities at the location and access costs. However, few houses have the same physical characteristics; Therefore, shopping-comparison is more complicated and more expensive in most other markets (HWANG; QUIGLEY, 2009).

Buyers, sellers, appraisers, and real estate agents estimate the market price of a house by using the information shown in the previously sold house set. The usefulness of these transactions as a reference and it depends on the similarities between them in many respects such as physical, space, and time. The inference of the "Market Price" of housing can only be drawn from the properties of past transactions for housing with different structures, taking advantage of different geographical attributes and being parties.

Different assessments according to different market conditions over time. Because housing is often traded, the emergence of new information about market value is slow. From the latest information and transactions that can be compared to different sizes, it may be the last transaction of the same place.

\section{- H1: Price has a positive effect on intention to buy townhouses.}

Developer brand can be understood as the name, term, symbol, drawing, or combination between them to confirm the product of the seller and to distinguish it from competitors' products (KOTLER, 2004). According to Manudo (2007), the research presented on brand awareness is an aspect affecting customer satisfaction. The more popular the brand, the higher the level of awareness, the more likely it is to affect the customer's intentions. 
DOI: 10.14807/ijmp.v11i6.1099

\section{- H2: Developer brand has a positive effect on intention to buy townhouses.}

Location is closely related to distance from various points of interest. Some of the various points of interest to be considered by house buyers are the distance to the central business district, distance to school, and distance to work and distance to retailer outlets (ADAIR et al., 1996; CLARK et al., 2006; OPOKU; ABDUL-MUHMIN, 2010; TU; GOLDFINCH, 1996; NGUYEN, 2013; VO, 2013; VO, 2016; PHAM, 2013). In Malaysia, studies also found that locational attributes appeared to support previous studies' findings whereby location was considered an essential consideration for house buyers (RAZAK et al., 2013).

\section{- H3: Location has a positive effect on intention to buy townhouses.}

A unique feature is an attribute of a product that responds to the satisfaction of consumers' needs and desires through the possession, use, and exploitation of products (KOTLER et al., 2007). Also, housing characteristics are outstanding factors such as construction quality, construction time, design, and scale of the house. When customers intend to buy houses, they will pay attention to the above factors (JULIUS et al., 2016).

\section{- H4: Housing characteristics have a positive effect on intention to buy townhouses.}

Opinions of friends, family decisions, or advice from sales experts also significantly affect the intention of choosing consumers' houses. Every individual always has people around who influence their buying decisions, including relationship, family, role, and status (personal) (PERRAEAU, 2014). A consumer is an individual, but will still belong to a group. The group of consumers is called a membership group. The second group is the reference group; this group will affect consumers' image and consumer behavior (decision). It is usually divided into three types of reference groups: family, close friends, neighbors, colleagues, and acquaintances (KOTLER; ARMSTRONG, 2010; KHAN, 2006) Family members may affect consumer behavior of consumer individuals. A family creates the first perceptions of the brain or consumer products and habits (KOTLER et al., 2010; KHAN, 2006)

- H5: Social influence has a positive effect on intention to buy townhouses.

Kim (2007) participated in the Hedonic regression model to consider the impact of legal impact on home buyers; Pham (2011) also mentioned that legal is one of the essential factors affecting real estate investment in Ho Chi Minh City. The legal factor is one of the most crucial 
DOI: 10.14807/ijmp.v11i6.1099

issues when choosing to buy the property. Therefore, this study uses legal as one of the research factors.

- H6: Legal has a positive effect on intention to buy townhouses.

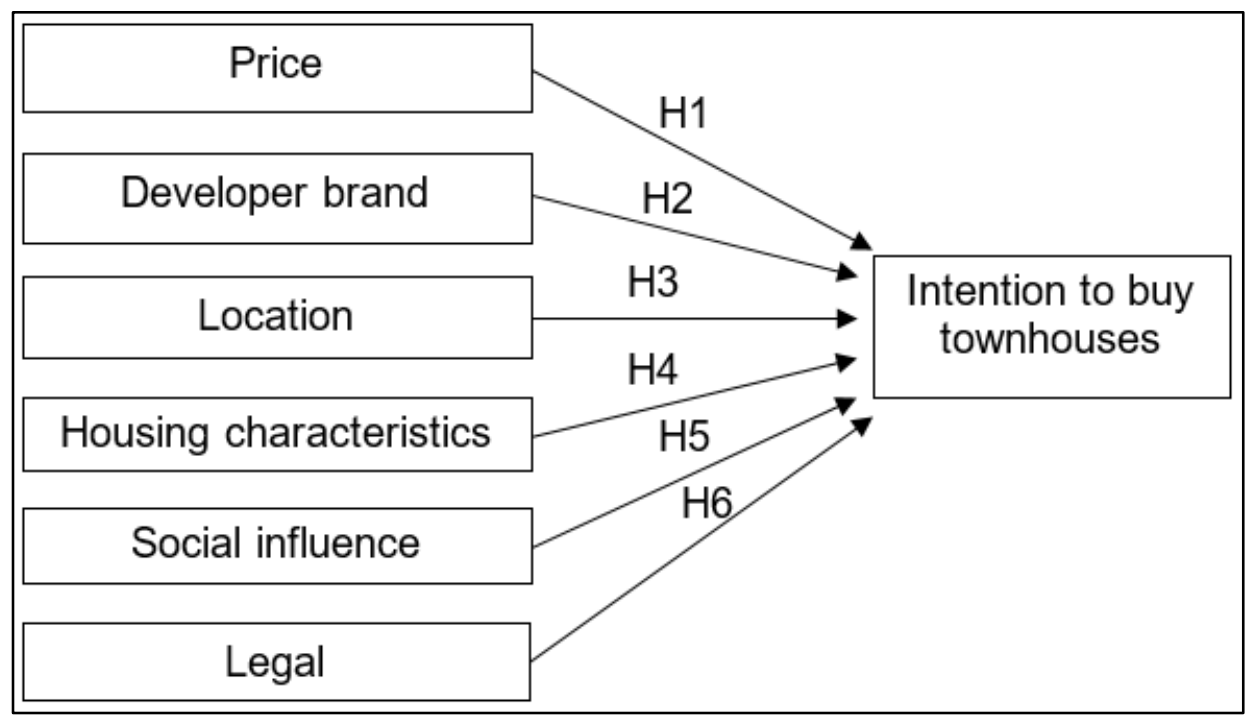

Figure 1: Proposed research model of the authors

This research is based on quantitative research, and the factors affecting the intention to buy a client's apartment with five factors that combine scales such as a nominal scale and Likert with five levels: (1) strongly disagree, (2) disagree, (3) neutral, (4) agree, (5) strongly agree to measure values. The study was carried out with 25 variables. The sample size must be at least 125 elements (= $5 * 25$ observed variables) to meet the condition of the minimum number of observations. So choose 200 as the number of research samples for the report. The analytical data were collected by non-probability sampling method according to the convenient sampling method in Ho Chi Minh City in the period from January 2019 to March 2019. Study to use the method of measuring scales with Cronbach's Alpha coefficients, exploratory factor analysis (EFA), and regression analysis.

\section{ANALYSIS AND RESULTS}

\subsection{Data description:}

After the two months to conduct the survey from January to March in 2019 and do data analysis in the final three weeks of April, the authors collected 192 valid respondents out of 200 respondents, accounting for $96 \%$ and the following table can describe the data:

Table 1: Data description

\begin{tabular}{|c|c|c|c|}
\hline & & Frequency & Percent \\
\hline \multirow{2}{*}{ Gender } & Male & 112 & $583 \%$ \\
\hline & Female & 82 & $41.7 \%$ \\
\hline
\end{tabular}


ISSN: $2236-269 X$

DOI: 10.14807/ijmp.v11i6.1099

\begin{tabular}{|l|l|l|l|}
\hline \multirow{5}{*}{ Age } & Under 25 years old & 41 & $21.4 \%$ \\
\cline { 2 - 4 } & From 25 to 35 years old & 57 & $29.7 \%$ \\
\cline { 2 - 4 } & From 35 to 50 years old & 56 & $29.2 \%$ \\
\cline { 2 - 4 } & Over 50 years old & 38 & $19.8 \%$ \\
\hline \multirow{5}{*}{ Education } & Undergraduate high school & 16 & $8.3 \%$ \\
\cline { 2 - 4 } & Technical school. & 46 & $24 \%$ \\
\cline { 2 - 4 } & Colleges & 60 & $31.3 \%$ \\
\cline { 2 - 4 } & University & 53 & $27.6 \%$ \\
\cline { 2 - 4 } & Postgraduate & 17 & $8.9 \%$ \\
\hline \multirow{5}{*}{ Incob } & State employees and officials & 40 & $20.8 \%$ \\
\cline { 2 - 4 } & Workers and Employees & 58 & $30.2 \%$ \\
\cline { 2 - 4 } & Agricultural & 15 & $7.8 \%$ \\
\cline { 2 - 4 } & Businessman & 61 & $31.8 \%$ \\
\cline { 2 - 4 } & Other & 18 & $6.4 \%$ \\
\hline & Under 6 million VND / month & 37 & $19.3 \%$ \\
\cline { 2 - 4 } & From 6 to 15 million VND / month & 50 & $26.0 \%$ \\
\cline { 2 - 4 } & From 16 to 25 million VND / month & 48 & $25.0 \%$ \\
\cline { 2 - 4 } & From 25 to 35 million VND / month & 37 & $19.3 \%$ \\
\cline { 2 - 4 } & Over 35 million VND / month & 20 & $10.4 \%$ \\
\hline
\end{tabular}

Regarding gender: The majority of gender is male, with 112 people accounting for $58.3 \%$, while the number of female participants is 80 people, accounting for $41.7 \%$, and the data show that the gender gap is not high.

Regarding age: 57 people are from 25 to 35 years old, accounting for $29.7 \%$ and get the highest rate, the second is 67 people who are under 25 years old, accounting for $33.3 \%$, the third is 56 people who are from 35 to under 50 and accounting for $29.2 \%$, and 38 people are over 50 years old, accounting for $19.8 \%$ and get the lowest rate. Based on the analysis of age, customers in Ho Chi Minh City are mainly between 25 and 50 years old.

Regarding education background: According to the results, the education background has a quite high disproportion. Colleges have the highest number of respondents, which is 60 people, accounting for $31.3 \%$, while the university has 53 people, accounting for $27.6 \%$. Besides, Technical school has 46 people who join the survey, accounting for $24 \%$. Undergraduate high school who answers the survey is 16, accounting for $8.3 \%$. Finally, postgraduate has 17 participants, accounting $8.9 \%$.

Regarding job: businessman has 61 people, accounting 31.8\%. Secondly, workers and employees have 58 people, accounting at 30.2\%. The employees and officials have 40 people, accounting 20.8\%. Besides, agricultural has 15 people, accounting 15.8\%. Finally, other has 18 people, accounting $9.4 \%$.

Regarding income: 50 people are from 6 to 15 million VND/month, accounting for $26 \%$ and get the highest rate, the second is 48 people who are from 16 to 25 million VND/month, accounting for $25 \%$, the third is 37 people who are under 6 million VND/month or from 25 to 
INDEPENDENT JOURNAL OF MANAGEMENT \& PRODUCTION (IJM\&P)

http://www.ijmp.jor.br

v. 11, n. 6, September - October 2020

ISSN: 2236-269X

DOI: 10.14807/ijmp.v11i6.1099

35 million VND/month and accounting for 19.3\%, and 20 people are over 35 million $\mathrm{VND} /$ month, accounting for $10.4 \%$ and get the lowest rate. Based on the analysis of age, customers in Ho Chi Minh City are mainly between 6 and 25 million VND/month.

\subsection{Reliability test: Cronbach's Alpha}

According to Nunnally and Bernstein (1994), the condition to accepting variables is that Corrected Item - Total Correlation is equal or greater than 0.3 and Cronbach's Alpha if item deleted is equal or greater than 0.7. According to Nguyen and Ha (2008), Hoang and Chu (2007), Hoang and Chu (2008 $\left.{ }^{a}, 2008 b\right)$, Nguyen (2011), Hair et al. (2014), new studies can accept that Cronbach's Alpha, if item deleted, is equal or greater than 0.6.

Table 2: Constructs, corrected item - total correlation and Cronbach Alpha

\begin{tabular}{|c|c|c|c|}
\hline Items & Constructs & \multicolumn{2}{|c|}{ 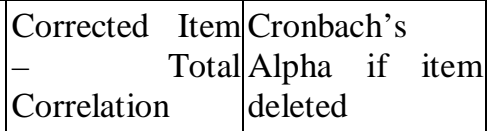 } \\
\hline \multicolumn{4}{|c|}{ Legal: Cronbach's Alpha=0.855 } \\
\hline LG1 & I like townhouses with clear legislation & .641 & .840 \\
\hline LG2 & Legal is a prime factor for me to buy a house & .662 & .831 \\
\hline LG3 & I want to buy a house with a certificate of ownership & .762 & .788 \\
\hline LG4 & I want the townhouse to have reliable legal status & .732 & .802 \\
\hline \multicolumn{4}{|c|}{ Housing characteristics: Cronbach’s Alpha $=.809$} \\
\hline HC1 & $\begin{array}{l}\text { I like townhouses in Ho Chi Minh City because there is a modern } \\
\text { infrastructure here }\end{array}$ & .705 & .723 \\
\hline HC2 & $\begin{array}{l}\text { I intend to buy a townhouse because of its convenient location for } \\
\text { travel }\end{array}$ & .609 & .769 \\
\hline HC3 & I intend to buy a townhouse because I can design my own house & .542 & .799 \\
\hline HC4 & $\begin{array}{l}\text { I intend to buy a townhouse because I think there is good security } \\
\text { here }\end{array}$ & .656 & .747 \\
\hline \multicolumn{4}{|c|}{ Developer brand: Cronbach's Alpha $=.870$} \\
\hline DB1 & Well-known brand owners will have high reputation & .728 & .832 \\
\hline DB2 & I want to buy a big brand house & 857 & .780 \\
\hline DB3 & I like to buy a home with a trusted brand owner & .598 & .860 \\
\hline DB4 & Developer brand name is the main factor affecting me & .723 & .835 \\
\hline \multicolumn{4}{|c|}{ Location: Cronbach’s Alpha $=.770$} \\
\hline LC1 & I intend to buy a house because it is near the work place of the family & .464 & .767 \\
\hline LC2 & I intend to buy a house because it is in a densely populated area & .586 & .707 \\
\hline LC3 & I like my home near the hospital school and the commercial center & .615 & .690 \\
\hline LC4 & Location is very important in leading to my intention to buy houses & .625 & .688 \\
\hline \multicolumn{4}{|c|}{ Social influence: Cronbach's Alpha $=.844$} \\
\hline SI1 & I intend to buy townhouses because of family impacts & .757 & .768 \\
\hline SI2 & I intend to townhouse because there are many family members & .778 & .760 \\
\hline SI3 & I intend to buy a house because my friends advised me & .602 & .835 \\
\hline SI4 & I intend to buy a house because of the media's mention & .595 & .840 \\
\hline \multicolumn{4}{|c|}{ Price: Cronbach’s Alpha $=.833$} \\
\hline PR1 & Prices are consistent with quality & .539 & .829 \\
\hline
\end{tabular}


INDEPENDENT JOURNAL OF MANAGEMENT \& PRODUCTION (IJM\&P)

http://www.ijmp.jor.br

v. 11, n. 6, September - October 2020

ISSN: 2236-269X

DOI: 10.14807/ijmp.v11i6.1099

\begin{tabular}{|l|l|l|l|}
\hline PR2 & $\begin{array}{l}\text { Selling price is the most important factor when considering to make a } \\
\text { home purchase intention }\end{array}$ & .642 & .797 \\
\hline PR3 & Payment schedule when buying a home is suitable for my income & .718 & .776 \\
\hline PR4 & I refer to and compare prices between investors before buying & .582 & .814 \\
\hline PR5 & I like discount when buying & .699 & .781 \\
\hline Intention to buy: Cronbach's Alpha .845 & .642 & .819 \\
\hline IB1 & I am planning to buy a house & .754 & .772 \\
\hline IB2 & I am trying to buy a house & .579 & .844 \\
\hline IB3 & I plan to continue buying houses in the future & .769 \\
\hline IB4 & I intend to buy the apartment because of the reputation of the Owner & .761 & \\
\hline
\end{tabular}

\subsection{Exploratory Factor Analysis (EFA)}

Exploratory Factor Analysis (EFA) is an analytical technique which is aimed to reduce data, so it is beneficial for identifying variables by the group. In the exploratory factor analysis, the authors used Principal Component Analysis and Varimax rotation to group the components.

\subsubsection{Independent variables}

The results show that $\mathrm{KMO}$ is 0.805 and can make sure the requirement $0.5<\mathrm{KMO}<1$. Bartlett is 2623.414 with sig $=0.00<0.05$, so all of the variables are correlation together in each component. Total variance explained equals $69.120 \%$, and it is greater than $50 \%$; as a result, it can meet the requirement of variance explained. From this one, this research can conclude that variables can explain $69.120 \%$ in changing factors. Also, eigenvalues equal $1.178>1$, and it is the fluctuation that can explain for each factor, so the extracted factors have a significant summarize in the best way. The rotated matrix in EFA show that the loading factor is higher than 0.50, and it can divide into six components by the following table:

Table 3: Rotated matrix

\begin{tabular}{|c|c|c|c|c|c|c|c|}
\hline \multirow{2}{*}{ Concepts } & \multirow{2}{*}{ Items } & \multicolumn{6}{|c|}{ Component } \\
\hline & & 1 & 2 & 3 & 4 & 5 & 6 \\
\hline \multirow{4}{*}{ Developer brand } & DB2 & .904 & & & & & \\
\hline & DB1 & .830 & & & & & \\
\hline & DB4 & .789 & & & & & \\
\hline & DB3 & .661 & & & & & \\
\hline \multirow{4}{*}{ Social influence } & SI2 & & .842 & & & & \\
\hline & SI1 & & .809 & & & & \\
\hline & SI4 & & .751 & & & & \\
\hline & SI3 & & .739 & & & & \\
\hline \multirow{5}{*}{ Price } & PR3 & & & .838 & & & \\
\hline & PR5 & & & .835 & & & \\
\hline & PR4 & & & .756 & & & \\
\hline & PR2 & & & .723 & & & \\
\hline & PR1 & & & .547 & & & \\
\hline \multirow{3}{*}{ Legal } & LG3 & & & & .839 & & \\
\hline & LG1 & & & & .771 & & \\
\hline & LG4 & & & & .755 & & \\
\hline
\end{tabular}


ISSN: $2236-269 X$

DOI: 10.14807/ijmp.v11i6.1099

\begin{tabular}{|c|c|c|c|c|c|c|c|}
\hline & LG2 & & & & .668 & & \\
\hline \multirow{4}{*}{$\begin{array}{c}\text { Housing } \\
\text { characteristics }\end{array}$} & HC1 & & & & & .894 & \\
\hline & HC4 & & & & & .858 & \\
\hline & HC2 & & & & & .589 & \\
\hline & HC3 & & & & & .519 & \\
\hline \multirow{4}{*}{ Location } & LC4 & & & & & & .809 \\
\hline & LC3 & & & & & & .802 \\
\hline & LC2 & & & & & & .779 \\
\hline & LC1 & & & & & & .655 \\
\hline \multicolumn{2}{|l|}{ KMO } & \multicolumn{6}{|c|}{0.805 (sig. $=0.000)$} \\
\hline \multirow{2}{*}{\multicolumn{2}{|c|}{$\begin{array}{l}\text { Bartlett's } \\
\text { Eigenvalues }\end{array}$}} & \multicolumn{6}{|c|}{2623.414} \\
\hline & & 6.124 & 3.741 & 2.607 & 1.925 & 1.704 & 1.178 \\
\hline \multicolumn{2}{|c|}{ Total Variance Explained } & 13.814 & 6.417 & 38.678 & 49.324 & 59.300 & 69.120 \\
\hline
\end{tabular}

\subsubsection{Dependent variable:}

The results show that $\mathrm{KMO}$ is 0.699 and can make sure the requirement $0.5<\mathrm{KMO}<1$. Bartlett is 390.753 with sig $=0.00<0.05$, so all of the variables are correlation together in each component. Total variance explained equals $68.861 \%$, and it is greater than $50 \%$; as a result, it can meet the requirement of variance explained. Besides, eigenvalues equal $2.754>1$, and it is the fluctuation that can explain for each factor, so the extracted factors have a significant summarize in the best way. Finally, all of the variables have the loading factor that is greater than 0.50 and meet the requirement.

Table 4: Dependent variable, and testing

\begin{tabular}{|l|c|c|}
\hline \multicolumn{2}{|c|}{ Dependent variable } & Component \\
\cline { 2 - 3 } & IB4 & 1 \\
\cline { 2 - 3 } & IB2 & .887 \\
\cline { 2 - 3 } Intention to buy & IB1 & .886 \\
\cline { 2 - 3 } & IB3 & .794 \\
\cline { 2 - 3 } & & .743 \\
\hline KMO & $0.699($ sig. $=0.000)$ \\
\hline Bartlett's & 390.753 \\
\hline Eigenvalues & 2.754 \\
\hline Total Variance Explained & $68.861 \%$ \\
\hline Cronbach's Alpha & 0.718 \\
\hline
\end{tabular}

\subsection{Regression}

Regression analysis finds out what is the factor influencing customers' intention to buy townhouses and measures the impact of these factors. Before doing the regression analysis, the authors do compute the mean value of these factors. Whereas:

LG: Legal (PL1, PL2, PL3, PL4)

PR: Price (PR1, PR2, PR3, PR4, PR5)

LC: Location (LC1, LC2, LC3, LC4)

HC: Housing characteristics (HC1, HC2, HC3, HC4) 
DOI: 10.14807/ijmp.v11i6.1099

DB: Developer brand (DB1, DB2, DB3, DB4)

SI: Social influence (SI1, SI2, SI3, SI4)

IB: Intention to buy (IB1, IB2, IB3, IB4)

The following formula can describe regression analysis model in this research:

$$
I B=\beta 0+\beta 1 * L G+\beta 2 * P R+\beta 3 * S I+\beta 4 * D B+\beta 5 * L C+\beta 6^{*} H C
$$

Meanwhile, IB is a dependent variable, and it can measure the impact on the intention to buy townhouses in District 9 in Ho Chi Minh City and LG, SI, PR, DB, LC, and HC are independent variables can measure legal factors, social influence, price, developer brand, location, and housing characteristics.

Table 5: Regression results

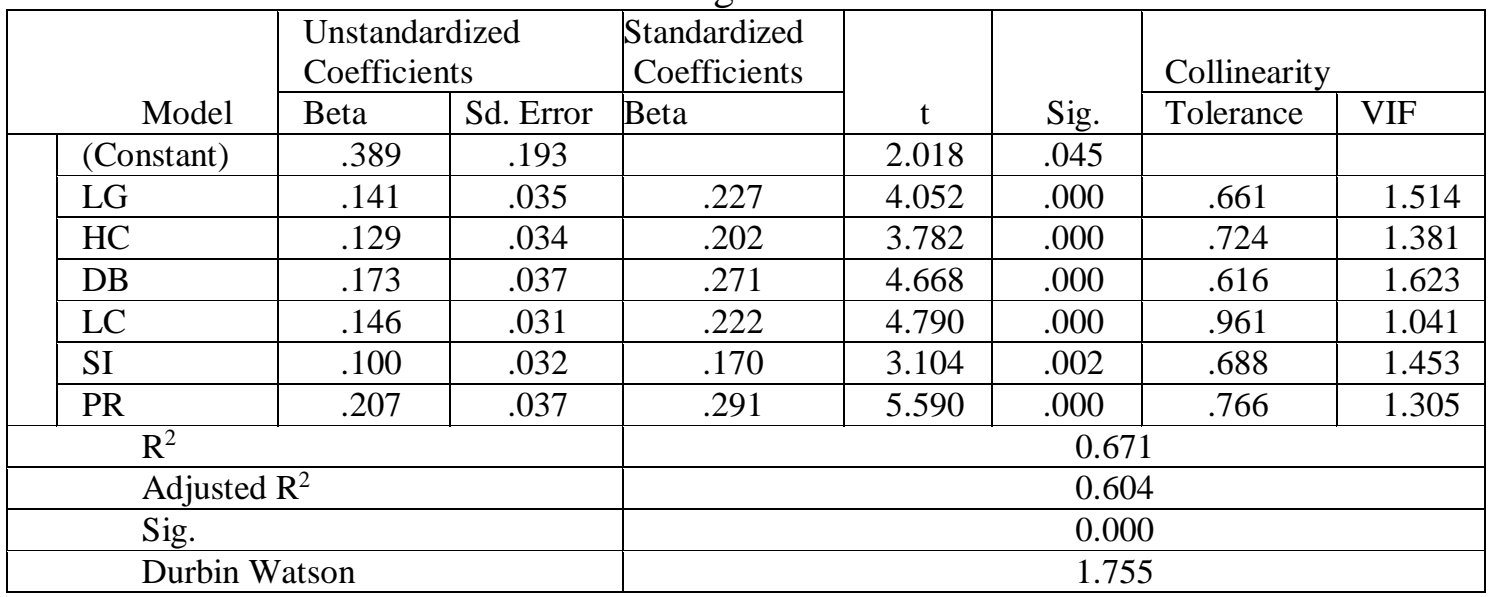

From the results of the regression model, all six variables have a significant statistic because their sig is less than 0.05. Therefore, these variables affect the intention to buy townhouses in District 9 in Ho Chi Minh City.

The adjusted R2 value is 0.604 , and it means that $60.4 \%$ of the intention to buy houses in District 9 is from 6 factors and $39.6 \%$ of that is from the factors which are outside of the model. The sig value is 0.000 , and it is less than 0.05 , so the research model is fit, and the variables which use in the model have a significant statistic. Besides, Durbin - Watson is 1.755, and as a result, there is no autocorrelation between the residuals in the model. What is more, variance inflation factors (VIF) are too small, and these point out that there is no multicollinearity in this model, so all of the independent variables do not correlate together.

The multiple regression model by standardized coefficients can be identified:

$$
I B=0.141 * L G+0.129 * H C+0.173 * D B+0.146 * L C+0.100 * S I+0.207 * P R
$$


DOI: 10.14807/ijmp.v11i6.1099

Table 6: The hypotheses testing results

\begin{tabular}{|c|l|c|}
\hline Hypothesis & \multicolumn{1}{|c|}{ Content } & Result \\
\hline H1 & Price has a positive effect intention to buy townhouses. & Accepted \\
\hline H2 & $\begin{array}{l}\text { Developer brand has a positive effect intention to buy } \\
\text { townhouses. }\end{array}$ & Accepted \\
\hline H3 & $\begin{array}{l}\text { Location has a positive effect on intention to buy townhouses. } \\
\text { H4 }\end{array}$ & $\begin{array}{l}\text { Housing characteristics have a positive effect intention to buy } \\
\text { townhouses. }\end{array}$ \\
\hline H5 & $\begin{array}{l}\text { Social influence has a positive effect intention to buy } \\
\text { townhouses. }\end{array}$ & Accepted \\
\hline H6 & Legal has a positive effect intention to buy townhouses. & Accepted \\
\hline
\end{tabular}

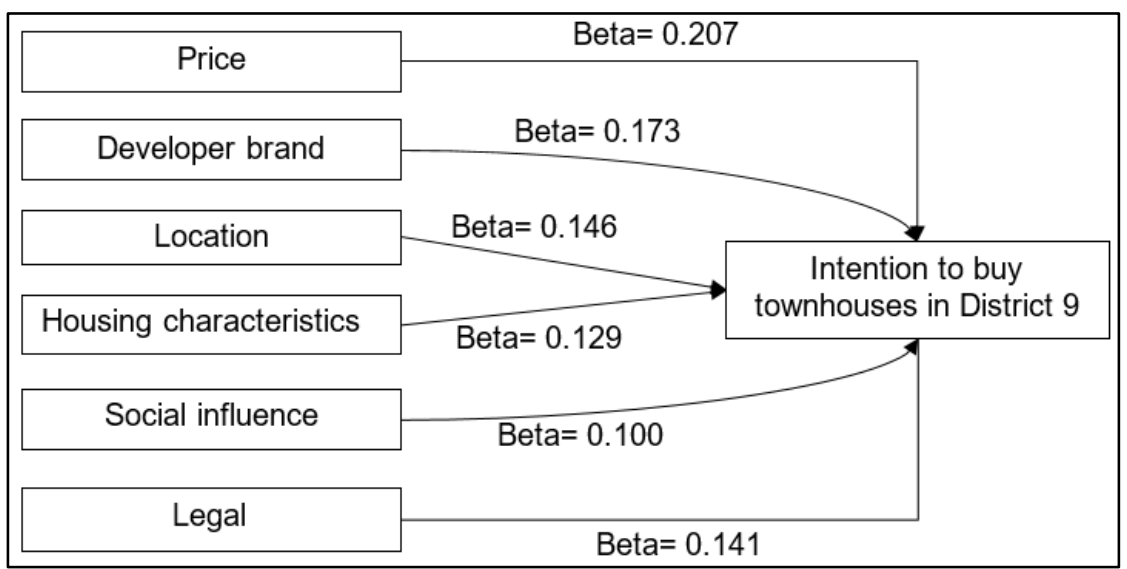

Figure 2: Factors affecting to intention to buy townhouses in District 9

\section{CONCLUSION}

This study is a succession and development based on previously proposed studies so that the results of the study have both similarities and differences. There are many similar research articles about the intention to buy real estate, however, to help businesses better understand the tastes and needs of customers in the real estate market from then on. Improving the quality of products and services and increasing the revenue of businesses, this paper has presented the theoretical basis for the intention of buying customers' houses and providing some relevant previous studies to the intention to buy a house. In the process of implementing the project, the actual survey process from customers is challenging; it takes a lot of time and effort to find customers to survey.

This research still has certain limitations such as: First, the duration of the study is short and only in a specific time so that the study may be correct only at present. Secondly, with a small number of samples and limited research conditions, the research may not reflect all current conditions objectively.

Through this paper, the authors give some recommendations for businesses operating in the real estate sector as follows: Regarding prices: businesses should relax the period of payment for customers, linking with other banks to lend to help customers buy motivation. As 
DOI: 10.14807/ijmp.v11i6.1099

for legal practice, at present, many projects that are legally entangled as customers become cautious when buying real estate, businesses should have policies to ensure customers, publicize legal documents for customers to verify and trust.

Regarding the social and brand influence of investors, businesses need to improve their reputation and reputation of the business as well as real estate products, helping customers understand the benefits and trust of businesses. Further research directions can be extended to study the factors affecting the intention to buy real estate (townhouses, land plots, apartments) of customers (domestic and foreign). It is also an open door for further research as well as businesses in real estate and related sectors.

\section{REFERENCES}

ADAIR, A.; BERRY, J.; MCGREAL, S. (1996) Valuation of residential property: Analysis of participant behaviour. Journal of Property Valuation \& Investment, v. 14, n. 1, p. 2035.

AJZEN, I.; FISHBEIN, M. (1975) Belief, Attitude, Intention and Behavior: An Introduction to theory and research, Addition-Wesley, Reading MA;

AJZEN, I. (1985) From intentions to actions: A theory of planned behavior. In KUHI, J.; J. BECKMANN, J. (Eds.) Action.control: From cognition to behavior, p. 11-39. Heidelberg: Springer.

AJZEN, I. (1991) The theory of planned behavior. Organizational Behavior and Human Decision Processes, v. 50, p. 179-211.

AJZEN, I.; FISHBEIN, M. (1975) Belief, attitude, intention and behavior. An Introduction to theory and research. Reading, Mass: Addison-Wesley.

APAPORN, L. (2013) Factors affecting the purchasing decisionof high-end condominium in Sathorn, Bangkok, Stamford International University;

BAGOZZI, R. P. (1983) A Holistic Methodology for Modelling Consumer Response to Innovation, Operations Research, v. 31, p. 128-176.

BENNAOR, A. C. (1995) Predicting Behaviour from Intention-to-Buy Measures: The Parametric case. Journal of Marketing Research, v. 32, p. 176-191.

BENNETT D. P. (1998) Dictionary of Marketing Terms, NTC Business Books;

CHARLES F. F, (2016) Real estate principles, $11^{\text {th }}$ edition, DF Institute, Inc.; d/b/a

Dearborn Real Estate Education;

CLARK, W.; DEURLOO, M.; DIELEMAN, F. (2006) Residential mobility and neighborhood outcomes. Housing Studies, v. 21, p. 323-342.

DODDS, W. B.; MONROE, K. B.; GREWAL, D. (1991) Effects of Price, Brand, and Store Information on Buyers' Product Evaluations. Journal of Marketing Research, v. 28, n. 3, p. 307-19.

GRANBOIS, D.; SUMMERS, J. O. (1974) Primary and Secondary Validity of Consumer Purchase Probabilities. Journal of Consumer Research, v. 1, p. 31-38. 
HADDAD, M.; JUDEH, M.; HADDAD, S. (2011) Factors affecting buying behavior of an apartment and empirical investigation in Amman, Jordan. Applied Sciences, Engineering and Technology, v. 3, n. 3, p. 234-239;

HAIR, F. J.; BACK, C. W.; BABIN, J. B.; ANDERSON, E. R.; (2014) Multivariate Data Analysis, London, Pearson;

HOANG, T.; CHU, N.M.N (2007) Data analysis of data with SPSS, Hong Duc Publishing House, TP. Ho Chi Minh;

HOANG, T.; CHU, N.M.N (2008a) Statistics of application in socio-economy, Statistical Publishing House, TP. Ho Chi Minh.

HOANG, T.; CHU, N.M.N, (2008b) Analysis of research data with SPSS, Hong Duc Publishing House, Ho Chi Minh city;

HOWARD, J. A.; SHETH, J. N. (1967) A Theory of Buyer Behavior, in Moyer, R. (ed.) “Changing Marketing System”, Proceedings of the 1967 Winter Conference of the American Marketing Association AMA, p. 253-262.

HWANG P. M.; QUIGLEY, J. M. (2002) Housing price dynamics in time and space: predictability, liquidity and investor returns, Journal of Real Estate Finance and Economics, v. 41, n. 1, p. 3-23.

JULIUS, C.; AMRAN, H.; ABDUL, W. M.; DAVID, M.; NOREINA, K. (2016) Understanding factors that influence house purchase intention among consumer in Kota Kinabalu: An application of buyer behavior model theory, Journal of Technology Management and Business, v. 03, n. 02, p. 99-110.

KHAN, M. (2006) Consumer Behaviour and Advertising Management. New Age International.

KIM, A. M. (2007) North versus South: The impact of social norms in the market pricing property rights in Vietnam. World Development, v. 35, n. 12, p. 2079-2095;

KOTLER, P.; ARMSTRONG, G. (2015) Principles of Marketing, London, Pearson;

LEVY D.; MURPHY L.; CHRISTINA, K. C. (2007) Influences and Emotions: Exploring Family Decision-making Processes when Buying a House, University of Auckland Business School.

MANUDO F. D. (2007) The influence of brand awareness on the relationship between perceivedservice and customer satisfaction in mobile telecommunications, Master thesis, MIT Taiwan.

MOROWITZ, V. G.; SCHMITTLEIN, D. (1992) Using Segmentation to Improve Sales Forecasts Based on Purchase Intent: Which Intenders Actually Buy?, Journal of Marketing Research, v. 29, p. 391-405.

MOROWITZ, V. G.; STECKEL, J.; GUPTA, A. (1996) When do Purchase Intentions Predict Sales?, (Working Paper, Stern School of Business, New York University, New York. MULLETT, G. M.; KARSON, M. J. (1985) Analysis of Purchase Intent Scales Weighted by Probability of Actual Purchase. Journal of Marketing Research, p. 93-96.

NEWBERRY, C. R.; KLEINZ, B. R.; BOSHOFF, C. (2003) Managerial Implications of Predicting Purchase Behaviour from Purchase Intentions: A Retail Patronage Case Study. Journal of Services Marketing, v. 17, p. 609-618. 
DOI: 10.14807/ijmp.v11i6.1099

NGUYEN, C. P. (2013) Factors affecting the intention to buy apartment, Danang University of Economics.

NGUYEN, D. T.; NGUYEN, T. M. T. (2007a) Market Research, National University Publishing House of Ho Chi Minh City;

NGUYEN, Đ. T. (2011) Methods of scientific research in business, Lao Dong-Social Publishing House;

NGUYEN, M. T.; HA, T. Q. (2008) Research data processing with SPSS for Windows, Industry University Publishing House, Ho Chi Minh city;

NUnnally, C.; BeRnstein, I. H. (1994) Psychometric theory, New York, McGrawHill Company;

OPOKU, R. A.; ABDUL-MUHMIN, A. G. (2010) Housing preferences and attribute importance among low-income consumers in Saudi Arabia. Habitat International, v. 34, p. 219-227.

PERREAU F. (2014) The Consumer Factor. The Consumer Buying Decision Process. http://theconsumerfactor.com/en/5-stages-consumer-buying-decisionprocess/ Accessed on 29 December 2014.

PHAM, T. P. L. (2011) Analysis of factors affecting real estate investment in Ho Chi Minh City, University of Economics Ho Chi Minh city;

PICKERING, J. F.; ISHERWOOD, B. C. (1974) Purchase Probabilities and Consumer Durable Buying Behaviour. Journal of the Market Research Society, v. 16, p. 203-226.

RAZAK, I.; IBRAHIM, R.; HOO, J.; OSMAN, I.; ALIAS, Z. (2013) Purchasing Intention towards Real Estate Development in Setia Alam, Shah Alam: Evidence from Malaysia. International Journal of Business, Humanities and Technology, v. 3, n. 6, p. 66-75.

REZVANI, S.; DEHKORDI, G. J.; RAHMAN, M. S.; FOULADIVANDA, F.; HABIBI, M.; EGHTEBASI, S. (2012) A Conceptual Study on the Country of Origin Effect on Consumer Purchase Intention. Asian Social Science, v. 8, n. 12.

SALAH, T. A.; EMMANUE, K; ADNAN, M. B.; ACHMAT, A. J. (2015) Behavioral Factors Affecting Real Estate Purchasing, Prince Sultan College for Business in Jeddah and Al-Faisal UniversityJeddah, Saudi Arabia.

SHEPPARD, B. H.; HATWICK, J.; WARSHAW, P. R. (1988) The Theory of Reasoned Action: A Meta nalysis of Past Research with Recommendations for Modifications and Future Research. Journal of Consumer Research, v. 15, p. 325-343.

SOLOMON, M. (2004) Consumer behavior. Sixth edition, Prentice Hall.

TA, T. H. H. (2009) Guide to Learning Customer Behavior, Open University in Ho Chi Minh City. Ho Chi Minh;

TIRTIROGLU, E.; ELBECK, M. (2008) Qualifying purchase intentions using queueing theory, Journal of applied quantitative methods, v. 3, n. 2, p. 167-178.

TU, Y.; GOLDFINCH, J. (1996) A two-stage housing choice forecasting model. Urban Studies, v. 33, n. 3, p. 517-537.

VO, P. T. N. (2013) Factors affecting the intention to buy houses of Ho Chi Minh City customers, University of Economics Ho Chi Minh city; 
DOI: 10.14807/ijmp.v11i6.1099

VO, T. T. L. (2016) Factors affecting the intention to buy houses of low-income people, Hong Bang International University;

WARSHAW, P. R. (1980) Predicting Purchase and Other Be-haviors from General and Contextually Specific Intentions. Journal of Marketing Research, v. 17, p. 26-33.

WHEATON, W. C. (1990) Vacancy, Search and Prices in a Housing Market Matching Model, Journal of Political Economy, v. 98, n. 6, p. 1270-1292. 